\title{
The Oldest Evolutionary Lineage of Trichoneura Loew, 1850 (Diptera, Limoniidae) and the First Evidence of This Genus in Cretaceous Spanish Amber
}

\author{
Iwona Kania-Kłosok ${ }^{1, * \mathbb{D}}$, Wiesław Krzemiński ${ }^{2} \mathbb{D}$, Katarzyna Kopeć ${ }^{2} \mathbb{D}$ and Antonio Arillo ${ }^{3} \mathbb{D}$ \\ 1 Department of Biotechnology, Institute of Biology and Biotechnology, University of Rzeszów, Zelwerowicza 4 \\ 35-601 Rzeszów, Poland \\ 2 Institute of Systematics and Evolution of Animals, Polish Academy of Sciences, Sławkowska 17, \\ 31-016 Kraków, Poland; wieslawk4@gmail.com (W.K.); k_slazyk@poczta.onet.pl (K.K.) \\ 3 Departamento de Biodiversidad, Ecología y Evolución, Facultad de Biología, Universidad Complutense, \\ 28040 Madrid, Spain; antonioarillo@gmail.com \\ * Correspondence: ikania@univ.rzeszow.pl or iwonakania@onet.eu; Tel.: +48-17-785-5458
}

Citation: Kania-Kłosok, I.;

Krzemiński, W.; Kopeć, K.; Arillo, A. The Oldest Evolutionary Lineage of Trichoneura Loew, 1850 (Diptera, Limoniidae) and the First Evidence of This Genus in Cretaceous Spanish Amber. Insects 2021, 12, 411. https:// doi.org/10.3390/insects12050411

Academic Editor: John O. Stireman III

Received: 24 March 2021

Accepted: 1 May 2021

Published: 3 May 2021

Publisher's Note: MDPI stays neutral with regard to jurisdictional claims in published maps and institutional affiliations.

Copyright: (c) 2021 by the authors. Licensee MDPI, Basel, Switzerland. This article is an open access article distributed under the terms and conditions of the Creative Commons Attribution (CC BY) license (https:// creativecommons.org/licenses/by/ $4.0 /)$.
Simple Summary: A new established subgenus (genus Trichoneura, family Limoniidae) from Lower Cretaceous Spanish amber represents the oldest lineage of the genus and exhibits a unique morphology of hypopygium characterized by a huge lobe on the gonocoxite. The discovery of this new subgenus sheds new light on the chronostratigraphic distribution and diversity of the genus Trichoneura and the evolution of the Limoniidae. The is oldest known species of Trichoneura and is important for understanding the evolution of this group of insects.

\begin{abstract}
A new subgenus Cretalinea subgen. nov. of Trichoneura (Diptera, Limoniidae) is established with one new species: Trichoneura (Cretalinea) xavieri subgen. et sp. nov. This is the first report of the genus Trichoneura in Spanish amber and the first record of the genus from the Lower Cretaceous period. The oldest described species of Trichoneura is compared with other species of the genus with particular reference to those known species from the Upper Cretaceous. A list and key of fossil species of Trichoneura are given.
\end{abstract}

Keywords: fossil insects; Cretaceous; Spanish amber; new species; new subgenus

\section{Introduction}

With regard to extant fauna, the genus Trichoneura Loew, 1850 [1] is sparse in its number of species and is found in three zoogeographical regions, primarily in the southern hemisphere. The genus Trichoneura is most rich in species in the Oriental region, where eight species of the genus have been recorded. Less abundantly they occur in the Afrotropical region (four species), and rarely in Australia/Oceania where only one species has been reported $[2,3]$.

This genus is represented in recent fauna by three subgenera: Ceratolimnobia Alexander, 1920 [4] (two species), Trichoneura Loew, 1850 [1] (one species) and Xipholimnobia Alexander, 1921 [5] (ten species). In the fossil record only one subgenus, Trichoneura occurs (Table 1).

We only know five species from the fossil record, four from Eocene Baltic amber. Only one species was previously known from the Cretaceous period, from Upper Cretaceous Canadian amber [6] (Table 1). A representative of the genus Trichoneura has been found recently for the first time in Spanish Cretaceous amber and is described herein. It is also the oldest representative of the genus Trichoneura. Thanks to this new discovery, it was possible to shift the stratigraphic range of the genus Trichoneura from the late Cretaceous to the early Cretaceous. This new, peculiar species from amber of Spain described herein, provides evidence of the existence of Trichoneura flies in the early Cretaceous. 
Table 1. List of species of Trichoneura previously known from fossil record.

\begin{tabular}{cccc}
\hline Species & Time Scale & Type of Material & Locality \\
\hline $\begin{array}{c}\text { Trichoneura (Trichoneura) } \\
\text { gracilistylus Alexander, 1931 [7] }\end{array}$ & Eocene & Baltic amber & Baltic area \\
\hline $\begin{array}{c}\text { Trichoneura (Trichoneura) } \\
\text { ritzkowskii Krzemiński, 1990 [8] }\end{array}$ & Eocene & Baltic amber & Baltic area \\
\hline $\begin{array}{c}\text { Trichoneura (Trichoneura) wegiereki } \\
\text { Kania, 2015 [9] }\end{array}$ & Eocene & Baltic amber & Baltic area \\
\hline $\begin{array}{c}\text { Trichoneura (Trichoneura) vulgaris } \\
\text { Loew, 1850 [1] }\end{array}$ & Eocene & Baltic amber & Baltic area \\
\hline $\begin{array}{c}\text { Trichoneura (Trichoneura) } \\
\text { canadensis Krzemiński et Teskey, } \\
1987 \text { [6] }\end{array}$ & Upper Cretaceous & Canadian amber & Canada \\
\hline
\end{tabular}

\section{Material and Methods}

The study was based on material from Cretaceous Spanish amber. The specimen comes from the upper Albian amber-bearing deposit of Peñacerrada I (Basque-Cantabrian Basin, near the village of Moraza, Province of Burgos) (Figure 1). The specimen is deposited at the Museo de Ciencias Naturales de Álava, (Vitoria, Spain).

The specimen was embedded in epoxy resin (EPO-TEK 301) $[10,11]$ which allowed physical protection and optimal study in ventral, lateral and dorsal views.

The biological inclusion was examined with a Nikon (SMZ25) stereomicroscope, Nikon SMZ 1500 equipped with a Nikon DS-Fi1 camera. The measurements were taken with NIS-Elements D 3.0 software. The length of the discal cell was given from its posterior edge to the point of connection of vein $\mathrm{m}-\mathrm{m}$ with vein $\mathrm{M}_{3}$. The length of hypopygium was measured from the posterior margin of tergite IX to the tip of the gonocoxite. The measurements were given only for undamaged structures, in millimeters ( $\mathrm{mm})$, and the length of scape, pedicel, flagellomeres and particular segments of palpus were given according to the pattern: antenna or palpus section number/length of this section, in millimeters. Drawings were made by tracing the photographs. The terminology, wing venation and male genitalia nomenclature followed that of [12-14].
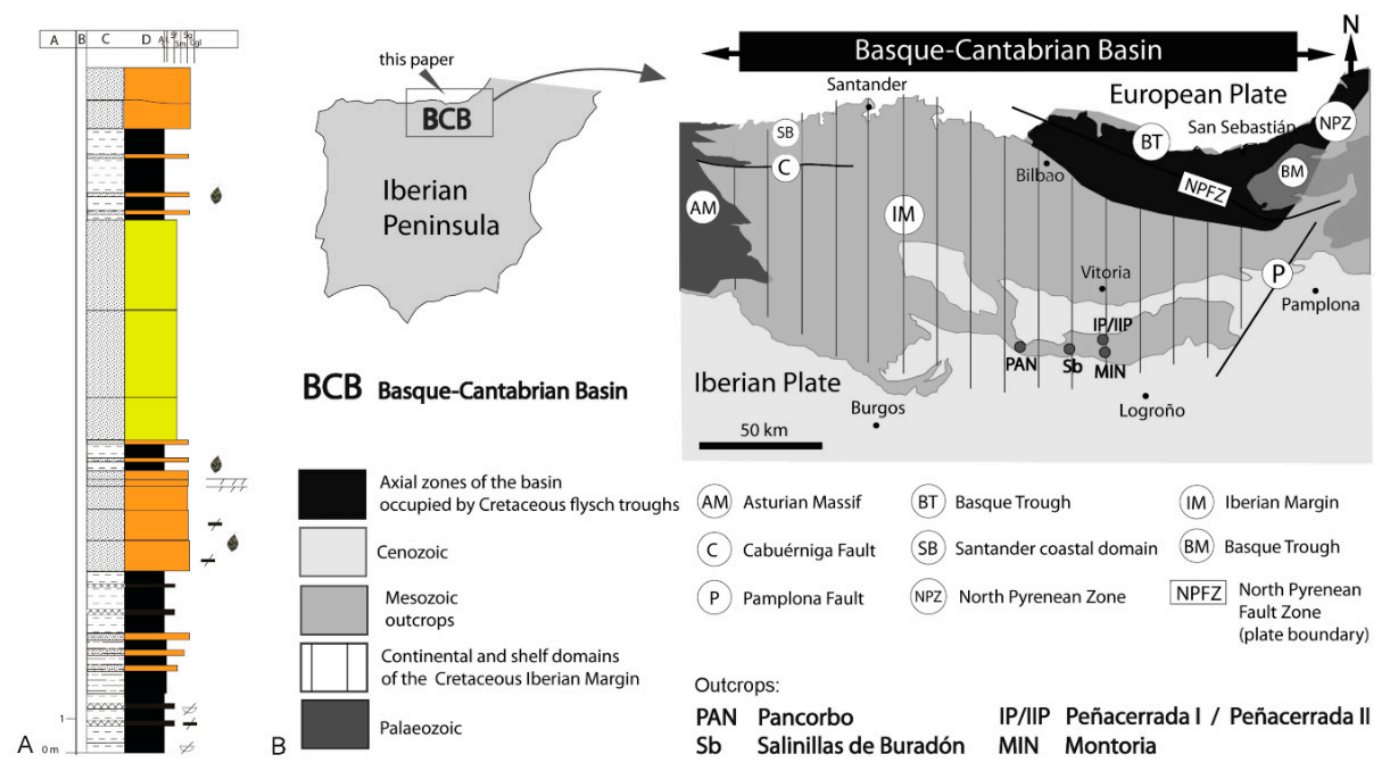

Figure 1. (A) Stratigraphic profile of the Peñacerrada I outcrop after [13], modified. (B) Geographical and geological setting with location of the studied section after [15] modified. 


\section{Results}

3.1. Systematic Paleontology

Order Diptera Linnaeus, 1758 [16]

Infraorder Tipulomorpha Rohdendorf, 1961 [17]

Family Limoniidae Speiser, 1909 [18]

Subfamily Limoniinae Speiser, 1909 [18]

Tribe Lechriini Alexander, 1927 [19]

Genus Trichoneura Loew, 1850 [1]

\subsection{Cretalinea subgen. nov.}

(Figures 2 and 3)
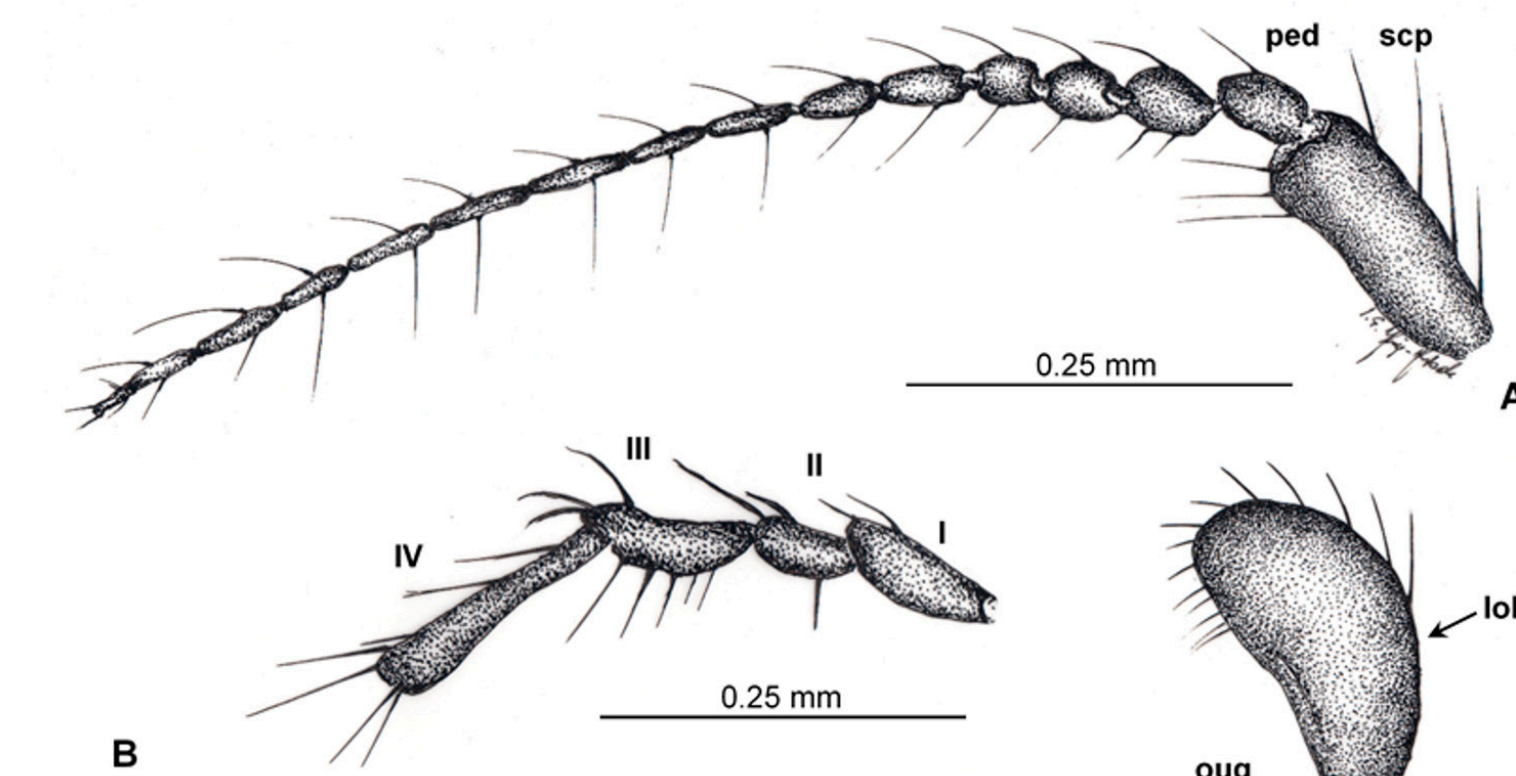

A
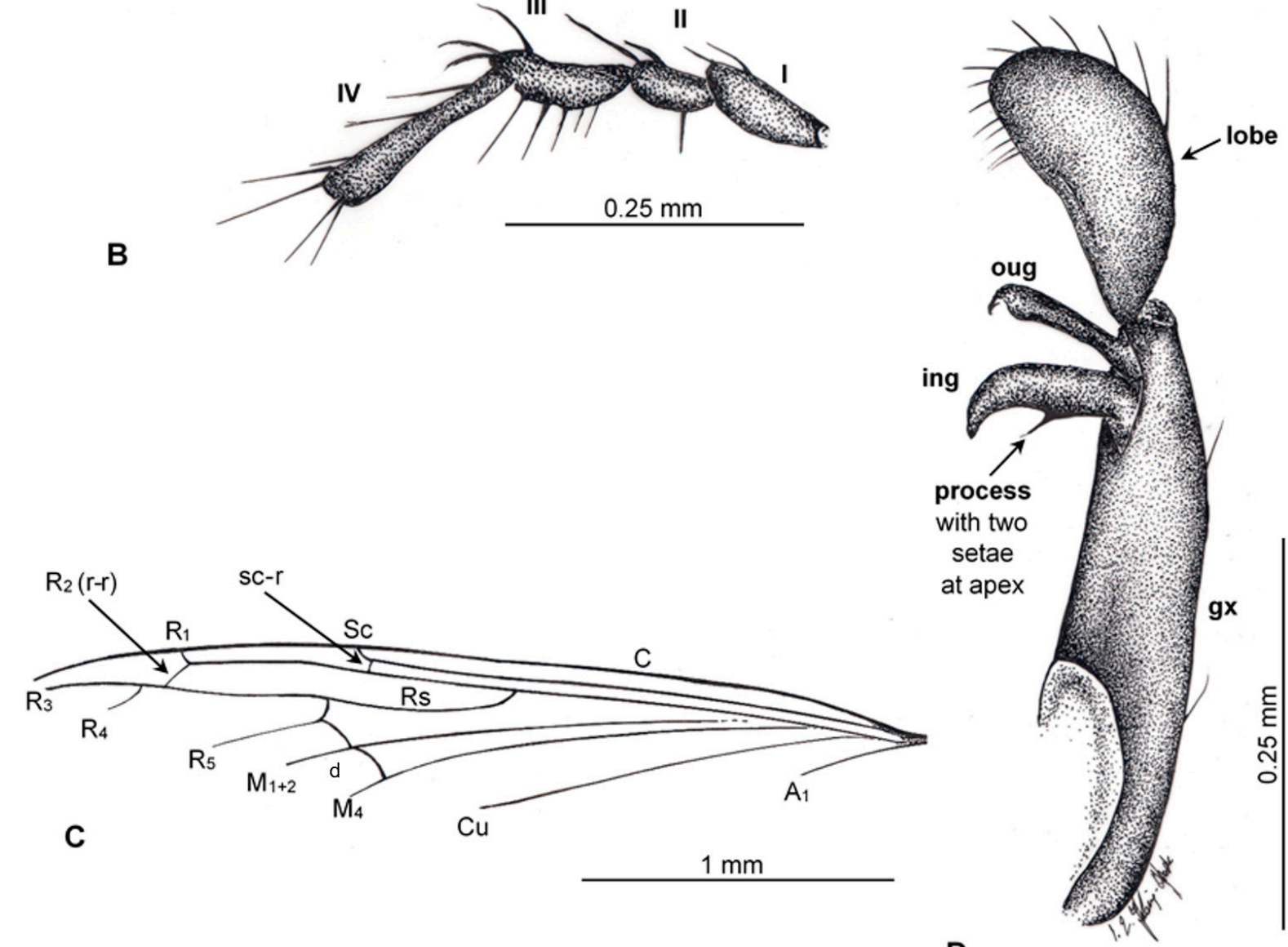

D

Figure 2. Trichoneura (Cretalinea) xavieri subgen. et sp. nov., holotype No. MCNA 9735 (male). (A) antenna; (B) palpus; (C) preserved of part of wing; (D) gonostyli and gonocoxites. Abbreviations: scp—scape; ped-pedicel; I-IV—palpomeres 1-4; ing-inner gonostylus; oug-outer gonostylus; gx-gonocoxite. 

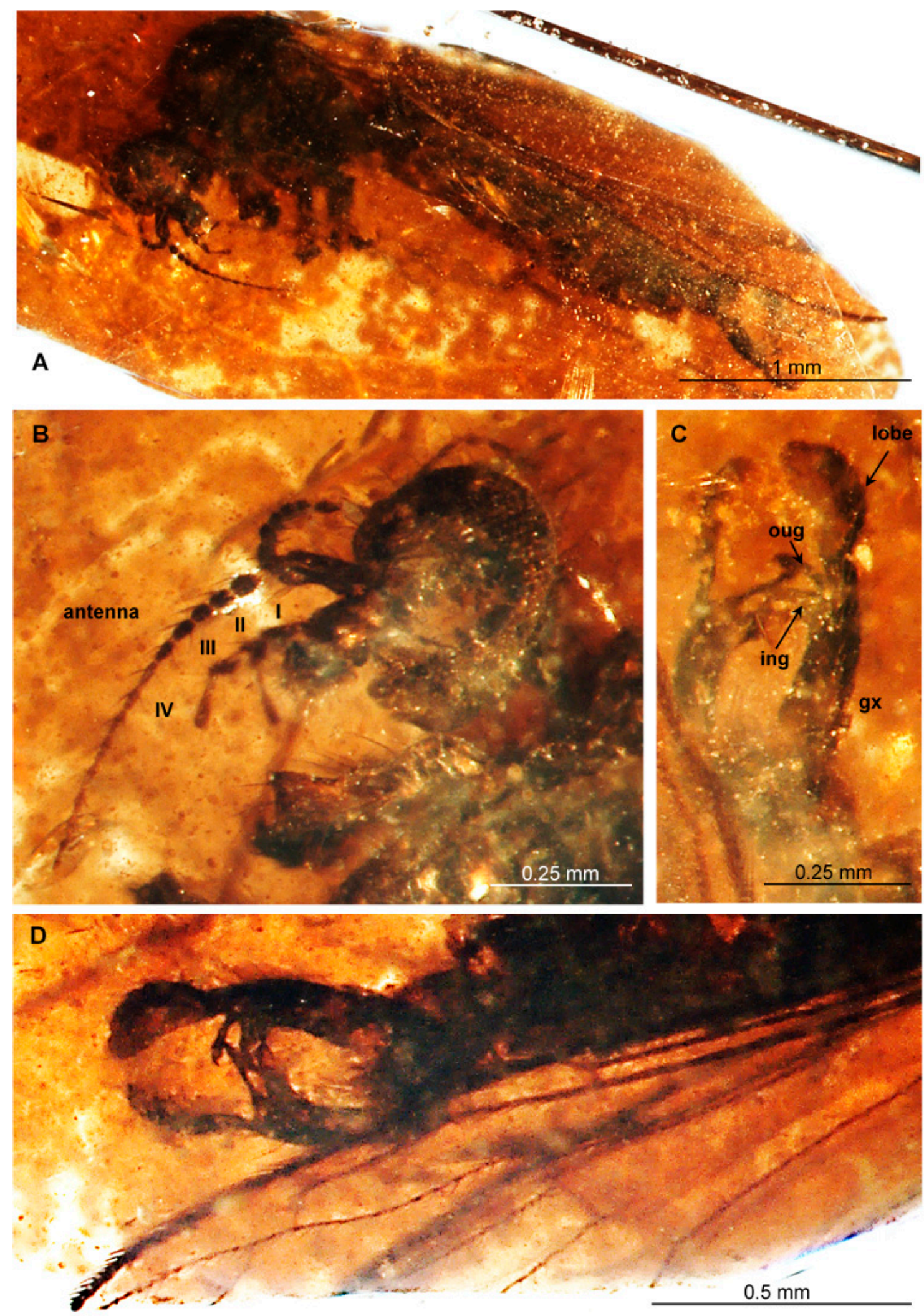

Figure 3. Trichoneura (Cretalinea) xavieri subgen. et sp. nov., holotype No. MCNA 9735 (male). (A) body, lateral view; (B) head with antenna and palpus visible; (C) hypopygium dorsal view; (D) hypopygium, ventral view. Abbreviations as in Figure 2. 
Type species. Trichoneura (Cretalinea) xavieri subgen. et sp. nov., Spanish amber, Lower Cretaceous, upper Albian.

Etymology. The subgenus name is derived from "creta" (Latin) = Cretaceous and "linea" (Latin) = line. Gender feminine.

Diagnosis. Vein $\mathrm{R}_{1}$ terminate in $\mathrm{C}$, opposite approximately $0.8 \times$ length of $\mathrm{R}_{2+3+4}$; $\mathrm{R}_{3+4}$ present, slightly shorter than $\mathrm{R}_{2}(\mathrm{r}-\mathrm{r})$; bifurcation of $\mathrm{Mb}$ before level of the tip of Sc; sc-r shorter than length of section of Sc between sc-r and tip of Sc; gonocoxite with huge, spoon-shaped lobe, which measures almost $0.5 \times$ the length of gonocoxite, lobe with relatively short, strong, sparsely distributed setae; outer gonostylus sclerotized, undivided, narrow, only slightly widened at apex, inner and outer gonostylus of comparable length, constitutes less than $0.5 \times$ the length of gonocoxite; pronotal appendages absent.

Comparison. In contrast to representatives of all other subgenera Trichoneura, the subgenus Cretalinea subgen. nov. differs by the morphology of the hypopygium, i.e., the presence of a spoon-shaped lobe at the apex of the gonocoxite, with relatively short, strong, sparsely distributed setae. The lobe measuring almost $0.5 \times$ the length of the gonocoxite, approximately four times longer than wide, and the gonostylus measuring less than $0.5 \times$ the length of the gonocoxite. While the subgenera Ceratolimnobia and Trichoneura is characterized by a rather short gonocoxite, at most $2.5 \times$ as long as wide, and with at least one gonostylus longer than $0.5 \times$ the length of the gonocoxite. Moreover, in Ceratolimnobia a characteristic process occurs on the outer gonostylus and pronotal appendages are present on antepronotum [20], the pronotal appendages do not occur in Cretalinea subgen. nov. Whitish longitudinal lines on the thorax, which occur in Ceratolimnobia and are well visible in lateral view, do not occur in the Cretalinea subgen. nov. In Xipholimobia, the outer gonostylus is deeply bifid, the tip of vein $R_{1}$ is reduced or appears as a short spur [3], whereas in Cretalinea subgen. nov. the outer gonostylus is undivided and the tip of $R_{1}$ is well developed, and terminating in $\mathrm{C}$.

Description. Body brown, ca. $4 \mathrm{~mm}$ long. Head with eyes widely separated. Antenna longer than head, 16-segmented, scape cylindrical, elongate, longer than wide, massive, pedicel small, flagellomeres 3-5 wide and rather short, almost as long as wide; flagellomeres 6-16 elongate, cylindrical, becoming slender to the apex of the antenna; last flagellomere shortest and tiny; flagellomeres 1-15 each with two elongate setae. Maxillary palp four segmented, last palpomere elongate and narrow but widening towards apex.

Wing hyaline, vein Sc not very elongate, terminates before the Rs bifurcation level, beyond the fork of $\mathrm{Mb}$ level.

Hypopygium elongate and relatively narrow; gonapophyses small.

Key to subgenera of Trichoneura and fossil species of the genus. Compiled partly after key to fossil species of Trichoneura by [9].

1. Gonocoxite moderate in length, at most $2.5 \times$ as long as wide, without lobe at apex; at least one of gonostylus more than $0.5 \times$ the length of gonocoxite; outer gonostylus deeply

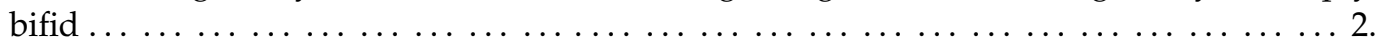

- Gonocoxite elongate, over $3 \times$ as long as wide, with huge lobe at apex, measuring approximately $0.5 \times$ the length of gonocoxite; gonostyli measuring less than $0.5 \times$ the length of gonocoxite; outer gonostylus undivided $\ldots \ldots \ldots \ldots \ldots \ldots \ldots \ldots$ $\ldots \ldots \ldots \ldots \ldots \ldots \ldots \ldots \ldots \ldots . \ldots \ldots$. (Cretalinea) xavieri subgen. et sp. nov.

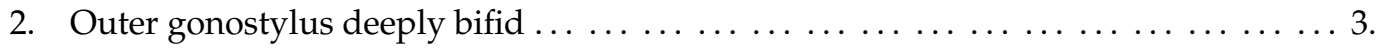

- Outer gonostylus undivided ... . . . . . . . . . . . T. (Trichoneura) Loew, 1850 [1] 4. 3. Vertex smooth, without corniculus or swelling near anterior end [3]; valves of the ovipositor unequal in length, exceedingly long, slender, a little shorter than the entire remainder of the abdomen [19]; pronotal appendages absent $[20] \ldots \ldots \ldots \ldots \ldots \ldots$

T. (Xipholimnobia) Alexander, 1921 [5]

Vertex with corniculus or swelling near anterior end [4]; valves moderate length, measuring more than $0.75 \times$ the length of entire reminder of the abdomen; pronotal appendages present [20] ... . . . . . . . . . . . . . . . . (Ceratolimnobia) munroi Alexander, 1920 [4] 
4. Tip of vein $R_{1}$ reduced; vein $R_{4}$ separating from $R_{2+3+4}$ far beyond separation of vein $R_{2}$, and with vein $R_{3}$ forming sector $R_{3+4}$, which measures approximately $0.5 \times$ the length of $R_{3}$; cross vein $\mathrm{m}$-cu positioned beyond $0.5 \times$ the length of $\mathrm{d}$-cell . . . . . . . T. (T.) canadensis - Tip of vein $R_{1}$ well developed, terminating in $C$; vein $R_{4}$ separate $R_{2+3+4}$ before or at the same point of separation of vein $R_{2}$; cross-vein $\mathrm{m}$-cu positioned before or at $0.5 \times$ the

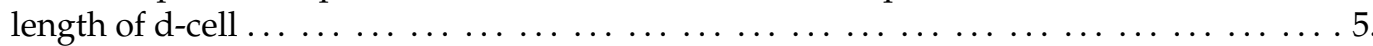
5. Vein Sc short, terminate opposite $0.75 \times$ of Rs; interbase of male genitalia curved at a

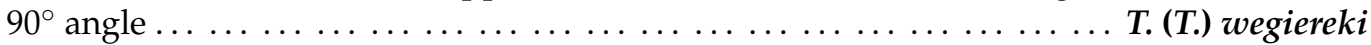
- Vein Sc elongate, terminate opposite approximately $0.85 \times$ of Rs or at fork of Rs; interbase of male genitalia straight or slightly arched $\ldots \ldots \ldots \ldots \ldots \ldots \ldots \ldots \ldots \ldots \ldots$ 6. Vein $\mathrm{R}_{3}$ longer than vein $\mathrm{R}_{2+3+4}$; outer gonostylus straight with tip not much wider than the base and provided with straight spine; inner gonostylus bent in the middle at an angle of almost $45^{\circ}$; aedeagus large and thick, nearly as long as the gonocoxite ....... $\ldots \ldots \ldots \ldots \ldots \ldots \ldots \ldots \ldots \ldots \ldots \ldots \ldots \ldots \ldots \ldots \ldots \ldots \ldots \ldots$ (T.) gracilistylus - Vein $\mathrm{R}_{3}$ at most as long as $\mathrm{R}_{2+3+4}$; outer gonostylus with tip conspicuously widened or narrowed; inner gonostylus only slightly bent; aedeagus small . . . . . . . . . 6 . 7. Vein Sc terminating before fork of Rs; $R_{3}$ distinctly shorter than $R_{2+3+4}$; outer gonostylus with strongly widened tip and spine curved inwardly, inner gonostylus with basal 0.3 of its length conspicuously widened and in distal 0.6 of its length strongly narrowed; aedeagus small, about half as long as gonocoxite; ninth tegite broadly excised with a depression in the middle $\ldots \ldots \ldots \ldots \ldots \ldots \ldots \ldots \ldots \ldots \ldots \ldots \ldots \ldots \ldots \ldots \ldots \ldots$. (T.) vulgaris - Vein Sc elongate, terminating level with fork of $R s ; R_{3}$ subequal or only slightly shorter than $\mathrm{R}_{2+3+4}$; outer gonostylus short with very broad base, its distal half strongly narrowed, tip blunt, spineless; inner gonostylus narrowed st 0.3 of its length; aedeagus somewheat longer than the half of gonocoxite $\ldots \ldots \ldots \ldots \ldots \ldots \ldots \ldots \ldots$. (T.) ritzkowskii

\subsection{Trichoneura (Cretalinea) xavieri sp. nov.}

(Figures 2 and 3)

Diagnosis. As for subgenus.

Etymology. The specific epithet is dedicated to eminent geologist and paleontologist Xavier Delclòs from the Universitat de Barcelona, Spain.

Material examined. Holotype No. MCNA 9735 (male), Peñacerrada, Álava, Spain, housed at the Museo de Ciencias Naturales de Álava, Vitoria, Spain.

Horizon and locality. The type specimen was found in amber from coal levels with abundant plant remains deposited in delta plain areas that correspond to the top of filling sequences of interdistributary bays. It is also found in filling deposits of abandoned fluvial channels or crevasse splay in the Utrillas Group [15], Lower Cretaceous, upper Albian. The outcrop of Peñacerrada I [21] is located in the Basque-Cantabrian Basin, municipality of Moraza (Province of Burgos, Castilla y León Autonomous Community, northern Spain).

Description. Body $3.96 \mathrm{~mm}$ long (Figure 2A), brown.

Head (Figure 2A,B): antenna (Figure 2A,B and Figure $3 \mathrm{~A}$ ) about $0.97 \mathrm{~mm}$ long $(1 / 0.18 \mathrm{~mm}$; 2/0.05 mm; 3/0.06 mm; 4/0.04 mm; 5/0.04 mm;6/0.05 mm; 7/0.05 mm; 8/0.05 mm; 9/0.04 mm; 10/0.06 mm; 11/0.06 mm; 12/0.06 mm; 13/0.07 mm; 14/0.06 mm; 15/0.04 mm; $16 / 0.06 \mathrm{~mm}$ ), scape approximately $3 \times$ longer than wide, with a few long and relatively strong elongate setae, longer than width of segments bearing them, $3 \times$ longer than pedicel, pedicel only $1.5 \times$ longer than first flagellomere, last flagellomere shortest and tiny, $3 \times$ longer than wide; flagellomeres 1-15 with two elongate setae, setae on last flagellomere rather short, last flagellomere with two rather short setae arranged at the tip of this segment of antennae. Maxillary palp (Figure 2A,B and Figure 3B) elongate, first and third palpomeres equal in length, $2 \times$ longer than wide, widened in distal part; second palpomere shortest, $1.5 \times$ longer than wide; last palpomere elongated and narrow, approximately $7 \times$ longer than wide, widened in apical part, length of palpomeres $0.47 \mathrm{~mm}$ : 1/0.12; 2/0.09 mm;3/0.14 mm; 4/0.12 mm.

Wing (Figure 2A,D and Figure $3 C$ ): Rs as long as $R_{2+3+4}$ and $R_{3+4}$ combined; fork of $R_{3+4}$ distal to $R_{1}$ insertion into $C$. 
Hypopygium (Figure 2C,D and Figure 3D): elongate and relatively narrow, $0.63 \mathrm{~mm}$ long, gonocoxite $0.40 \mathrm{~mm}$ long, inner gonostylus $0.14 \mathrm{~mm}$, outer gonostylus $0.12 \mathrm{~mm}$, lobe on hypopygium $0.23 \mathrm{~mm}$ long with relatively short, strong, sparsely distributed setae; inner gonostylus approximately twice width of outer gonostylus, process structure with two short setae at apex $0.5 \mathrm{x}$ the length of inner gonostylus, measuring $0.6 \mathrm{x}$ width of inner gonostylus.

Remarks. The specimen is not well preserved. Wings of the specimen are not clearly visible, and are only partially preserved. The legs are almost completely destroyed. The hypopygium is well preserved and the most important taxonomic features of the species are visible.

\section{Discussion}

Deposits of Spanish amber were formed in the Lower Cretaceous period in upper Albian later than the deposits of Lower Cretaceous Lebanese amber (lower Barremian [22,23]) and earlier than the Burmese amber deposits (Upper Cretaceous, Cenomanian [23]. Among the inclusions originating from this period there are many significant transformations of fauna and flora. Some of the oldest members of the subfamily Limoniinae e.g., the oldest representatives of the genus Helius Lepeletiere et Serville, 1928 [24] have been found in Lebanese amber - such as Helius ewa Krzemiński, Kania et Azar, 2014 [25] and Helius lebanensis Kania, Krzemiński et Azar, 2013 [26]. From Spanish amber, only three species of Limoniidae have been recorded until now: Alavia neli Krzemiński et Arillo, 2007 [27], Helius alavensis Kania, Krzemiński et Arillo, 2016 [28], and Helius spiralensis Kania, Krzemiński et Arillo, 2017 [29]. Added to these the newly described species-T. (Cretalinea) xavieri subgen. et sp. nov.- the oldest representative of the genus and new subgenus (Figure 4). The genus Trichoneura has so far been represented in the fossil record only by one subgenus, Trichoneura. In recent fauna, the subgenus Trichoneura is represented by only by one species, while the subgenus Xipholimnobia is the richest in species but is not present in the fossil record. There are more extant than fossil species, although the subgenus Ceratolimnobia is represented by only one species - Trichoneura (Ceratolimnobia) munroi (Alexander, 1920) [4]. Subgenera differ mainly in the morphology of the hypopygium and wing venation. The diversity of wings of fossil species belonging to the family and representatives of each subgenus are shown in Figure 5. There are clearly visible differences in the presence or reduction of the terminal sector of vein $R_{1}$, and development of $R_{3+4}$ as in T. (T.) canadensis (Figure 5). Five species from the fossil record, including a new species, T. (Cretalinea) xavieri subgen. et sp. nov., have obvious $R_{1}$. Due to the fact that there is a tendency to reduce the end of $R_{1}$, e.g. in Tipulidae Latreille, 1802 [30], it can be supposed that the well-developed $\mathrm{R}_{1}$ end is a plesiomorphic feature, and is more often characteristic of fossil species than modern ones. However, in Trichoneura this section of venation is variable, $R_{1}$ is sometimes obsolete, appearing as short spur.

It is also worth noting that all fossil species of the genus Trichoneura, both those known from the Cretaceous and the Eocene, have been found in the northern hemisphere, while most of the modern species classified to the genus occur in the southern hemisphere. This may be related to the climate, because deposits of resins such as Lebanese were formed in tropical or subtropical, moderate to hot and very wet, dense forests in the north-east of Gondwana [31], while Baltic amber deposits were formed during warming episode, in the Middle Eocene Climatic Optimum (MECO), the wormest period in Earth's history [32] Today, representatives of the genus Trichoneura are species associated with warmer areas on Earth including parts of Africa and Southeast Asia [2] (Figure 6). 


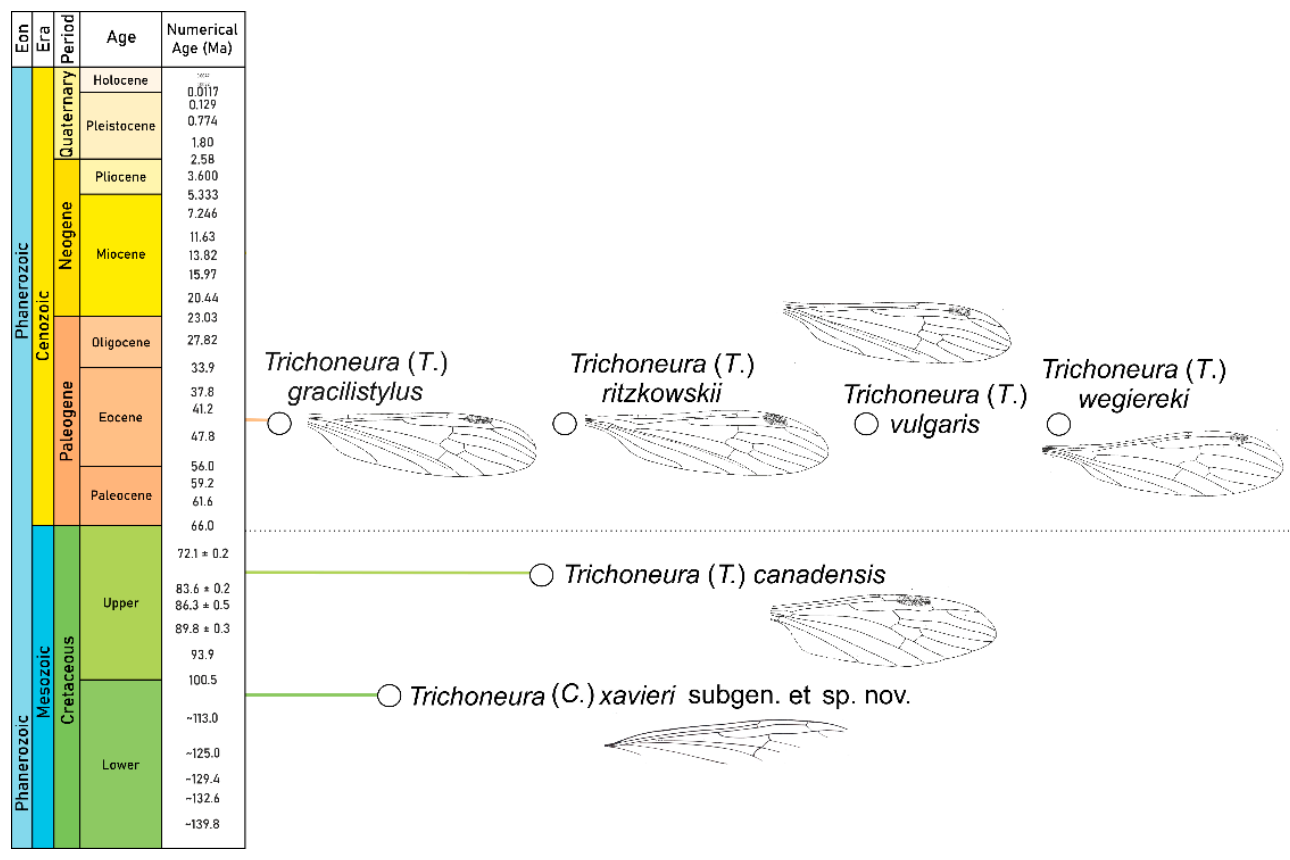

Figure 4. Chronostratigraphic distribution of Trichoneura, fossil species, redrawn after [1,6-9]. Chronostratigraphic chart and the colors of the lines that indicate age of extinct species of Trichoneura are used according to International Chronostratigraphic Chart v.2020.03 (https:/ / stratigraphy.org/chart) (accessed on 29 April 2021).

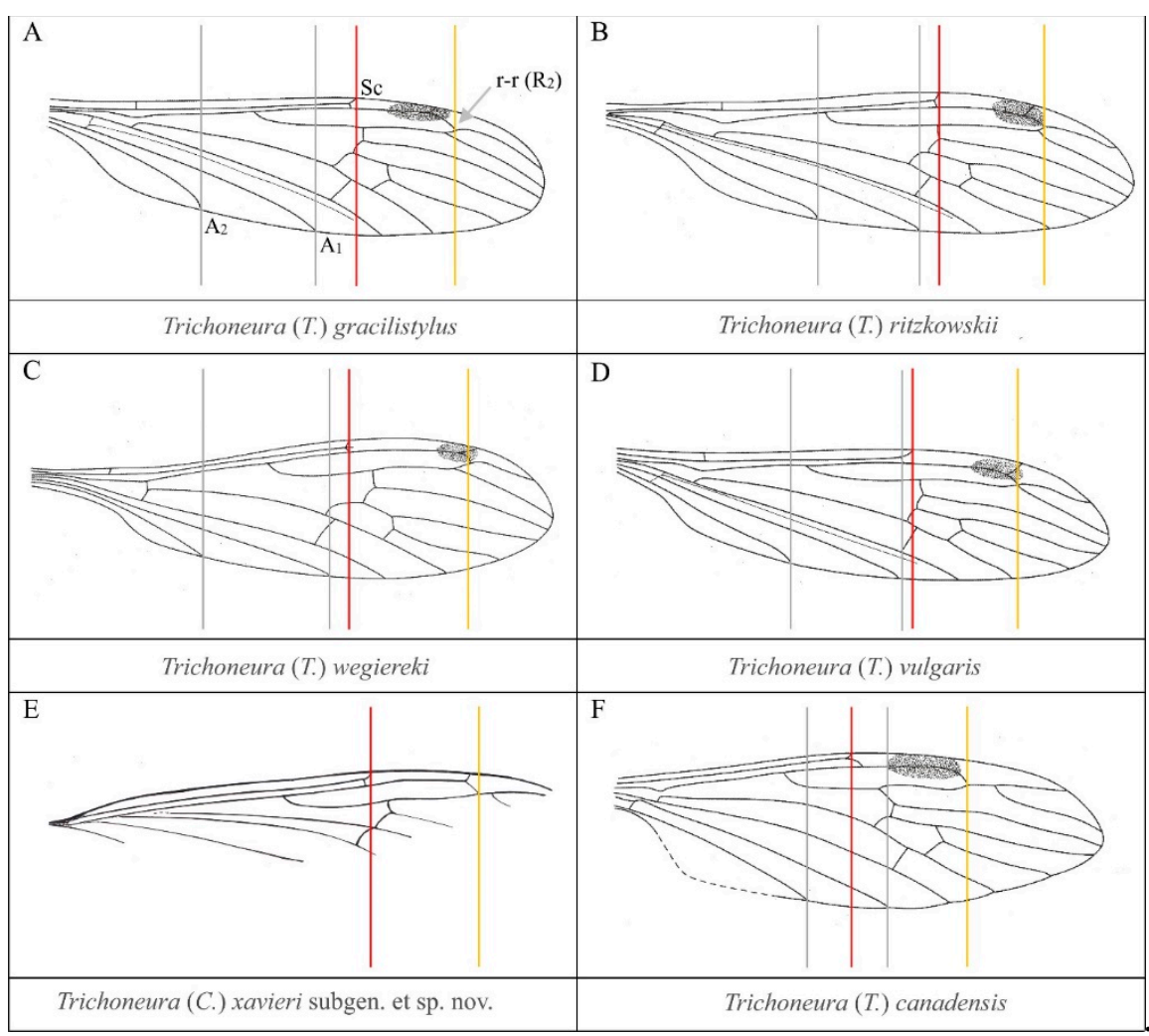

Figure 5. Wing venation of extinct species of the genus Trichoneura. Abbreviation: vertical lines indicate the line ends - grey lines tips of $A_{1}$ and $A_{2}$; red line, tip of Sc; yellow tip of $R_{1}$. The drawings are redrawn after [1,6-9]. 


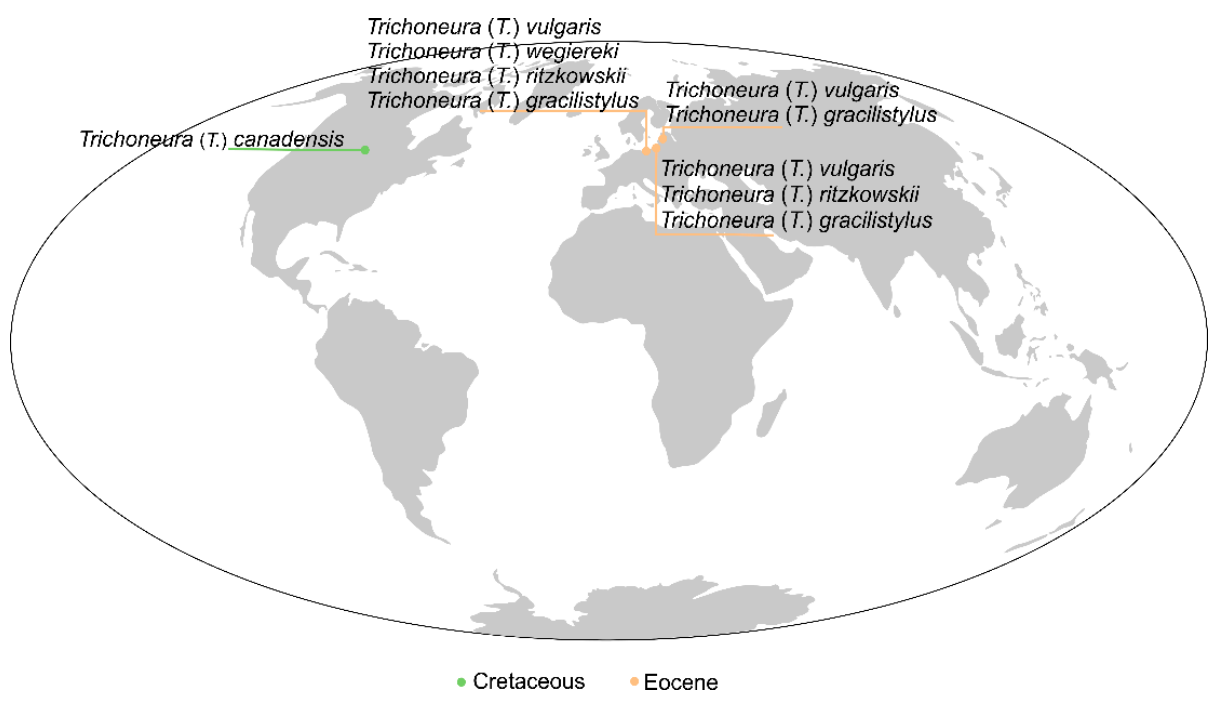

(A)

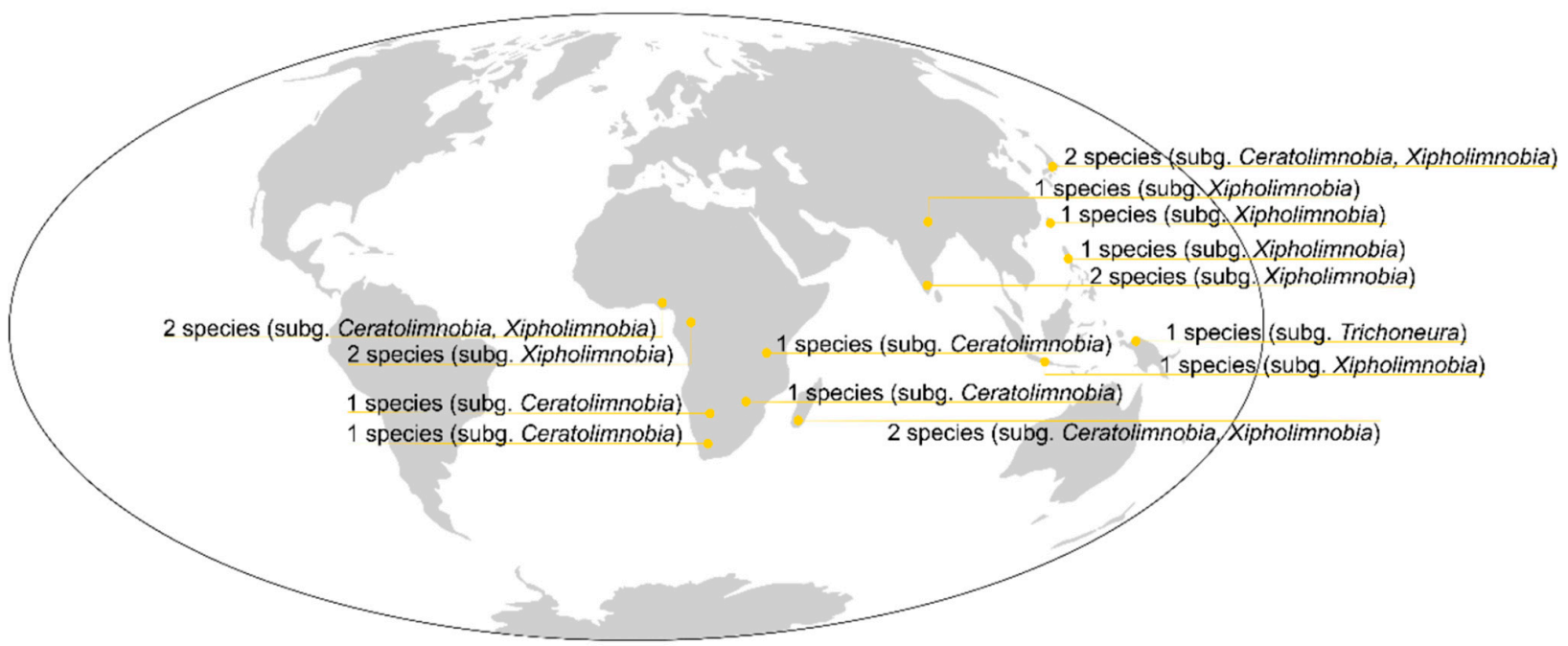

(B)

Figure 6. (A) Map of the distribution of fossil localities of the representatives of the genus Trichoneura. (B) Map of the distribution of the representatives of the genus Trichoneura in recent fauna (the data provided according to [2]). A. the colors of the lines that indicate fossil localities are used according to International Chronostratigraphic Chart v.2020.03 (https: / / stratigraphy.org/chart) (accessed on 29 April 2021).

\section{Conclusions}

Cretalinea subgen. nov. shows a unique morphology of hypopygium in which a relatively large, spoon-shaped lobe occurs measuring almost half the length of the gonocoxite. This particular structure of hypopygium is currently known only from one place and time, the Cretaceous Spanish amber period, and probably did not survive to recent times. This Cretaceous evolutionary lineage of Trichoneura provides the possibility to change the chronostratigraphic distribution of the genus from the late Cretaceous to the early Cretaceous. The newly discovered species is the oldest representative of Trichoneura and sheds new light on the evolution of this genus.

Author Contributions: Conceptualization: W.K., I.K.-K.; methodology: I.K.-K.; W.K.; format analysis: I.K.-K.; W.K; writing — original draft preparation: I.K.-K.; W.K; A.A.; review and corrections: W.K; I.K.-K.; A.A.; K.K. All authors have read and agreed to the published version of the manuscript. 
Funding: This research was funded by National Science Centre of Poland, grant number 2016/23/B/ NZ8/00936 and the APC was founded by National Science Centre of Poland, grant number 2016/23/B/ NZ8/00936.

Institutional Review Board Statement: Not applicable.

Informed Consent Statement: Not applicable.

Data Availability Statement: Data is contained within the article.

Acknowledgments: We would like to thanks Wiktoria Jordan-Stasiło (University of Rzeszów) for making the maps of the distribution of fossil localities of the representatives of the genus Trichoneura. This project was supported the grant CRE: Global bioevent of massive resin production at the initial diversification of modern forest ecosystems, funded by the Spanish AEI/FEDER, UE Grant CGL201784419. Open Access funding was enabled and organized by the National Science Centre of Poland under Grant no. 2016/23/B/NZ8/00936.

Conflicts of Interest: The authors declare no competing interests.

\section{References}

1. Loew, H. Über den Bernstein Und die Bernsteinfauna. Program Keiserischen Realschule Meseritz 1850, 2, 1-44.

2. Oosterbroek, P. Catalogue of the Crane-Flies of the World. (Diptera, Tipuloidea: Pediciidae, Limoniidae, Cylindrotomidae, Tipulidae). 2000. Last updated 28 December 2012. Available online: http://nlbif.eti.uva.nl/ccw/index.php (accessed on 1 February 2021).

3. Kato, D.; Tachi, T. The first records of the tribe Lechriini (Diptera: Limoniidae) in Japan, with descriptions of three new species. Euroasian Entomol. J. 2020, 19, 273-280.

4. Alexander, C.P. New or little-known Tipulidae (Diptera). III. Ethiopian species. Ann. Mag. Nat. Hist. 1920, 5, 465-472. [CrossRef]

5. Alexander, C.P. New or little-known Tipulidae (Diptera). IV. Ethiopian species. Ann. Mag. Nat. Hist. 1921, 7, 305-322. [CrossRef]

6. Krzemiński, W.; Teskey, H.J. New taxa of Limoniidae (Diptera: Nematocera) from Canadian amber. Can. Entomol. 1987, 119, 887-892. [CrossRef]

7. Alexander, C.P. Crane-flies of the Baltic amber (Diptera). Bernstein Forsch. 1931, 2, 1-135.

8. Krzemiński, W. Fossil Tipulomorpha (Diptera, Nematocera) from Baltic amber (Upper Eocene): Introductory part: Subfamily Lechriinae (Limoniidae). Polskie Pismo Entomol. 1990, 60, 177-194.

9. Kania, I. Subfamily Limoniinae Speiser, 1909 (Diptera, Limoniidae) from Baltic amber (Eocene): The genus Trichoneura Loew, 1850. Acta Zool. Crac. 2015, 58, 1-19. [CrossRef]

10. Corral, J.C.; López del Valle, R.; Alonso, J. El ámbar cretácico de Álava (Cuenca Vasco-Cantábrica, norte de España). Su colecta y preparación. Estud. Mus. Cienc. Nat. Álava 1999, 14, 7-21.

11. Nascimbene, P.; Silverstein, H. The preparation of fragile Cretaceous ambers for conservation and study of organismal inclusions. Studies on Fossils in Amber, with Particular Reference to the Cretaceous of New Jersey; Grimaldi, D., Ed.; Backhuys Publishers: Leiden, The Netherlands, 2000; pp. 93-102.

12. McAlpine, J.F.; Peterson, B.V.; Shewell, G.E.; Teskey, H.J.; Vockeroth, J.R.; Wood, D.M. Manual of Nearctic Diptera. In Research Branch Agriculture; Canada Communication Group Pub: Ottawa, ON, Canada, 1981; Volume 1, pp. $27-674$.

13. Krzemiński, W. Three new species of the genus Helius Lepeletier \& Serville (Diptera, Limoniidae) from the Middle Miocene of Stavropol (northern Caucasus, Russia). Acta Zool. Crac. 2002, 45, 317-320.

14. Ribeiro, G.C. Phylogeny of the Limnophilinae (Limoniidae) and early evolution of the Tipulomorpha (Diptera). Invertebrate Syst. 2008, 22, 627-694. [CrossRef]

15. Barrón, E.; Peyrot, D.; Rodríguez-López, J.P.; Meléndez, N.; López del Valle, R.; Najarro, M.; Rosales, I.; Comas-Rengifo, M.J. Palynology of Aptian and upper Albian (Lower Cretaceous) amber-bearing outcrops of the southern margin of the BasqueCantabrian Basin (northern Spain). Cretac. Res. 2015, 52, 292-312. [CrossRef]

16. Linnaeus, C. Systema Nature per Regna tria Naturae, Secundum Classes, Ordines, Genera, Species, cum Caracteribus, Differentiis, Synonymi, Locis, 10th ed.; Laurentii Salvii: Holmiae, UK, 1758; p. 824. [CrossRef]

17. Rohdendorf, B.B. The oldest infraorders of Diptera from the Triassic of Middle Asia. Palaeontol. Zhurnal 1961, 2, 90-100.

18. Speiser, P. 4 Orthoptera. Orthoptera Nematocera. Wissenschaftliche Ergebnisse der Schwedischen Zoologische Expededition nach Kilimandjaro. Meru 10 Diptera 1909, 31-65.

19. Alexander, C.P. Fauna Sumatrensis (Beitrag Nr. 39). Superfamily Tipuloidea (Dipt.) I. Suppl. Entomol. 1927, 15, 90-102.

20. Gavryushin, D.I. Six new species of limoniid flies (Diptera: Limoniidae) from Tanzania and notes on other species new to the country's fauna. Russ. Entomol. J. 2016, 25, 273-286. [CrossRef]

21. Peñalver, E.; Delclòs, X. Spanish Amber. In Biodiversity of Fossils in Amber from the Major World Deposits; Penney, D., Ed.; Siri Scientific Press: Manchester, UK, 2010; pp. 236-270.

22. Maksoud, S.; Azar, D. Lebanese amber: Latest updates. Palaeoentomology 2020, 3, 125-155. [CrossRef] 
23. Shi, G.; Grimaldi, D.A.; Harlow, G.E.; Wang, J.; Wang, J.; Yang, M.; Lei, W.; Li, Q.; Li, X. Age constraint on Burmese amber based on U-Pb dating of zircons. Cretac. Res. 2012, 37, 155-163. [CrossRef]

24. Le Peletier, A.L.M.; Serville, J.G.A. Entomologie, ou histoire naturelle des crustacés, des arachnides et des insectes. Encycl. Method. Hist. Nat. 1828, 10, 345-833.

25. Krzemiński, W.; Kania, I.; Azar, D. The Early Cretaceous evidence of rapid evolution of the genus Helius Lepeletier and Serville, 1828 (Limoniidae, Diptera). Cretac. Res. 2014, 48, 96-101. [CrossRef]

26. Kania, I.; Krzemiński, W.; Azar, D. The oldest representative of Helius Lepeletier \& Serville 1828 (Limoniidae, Diptera) from Lebanese amber (Early Cretaceous). Insect Syst. Evol. 2013, 44, 1-8.

27. Krzemiński, W.; Arillo, A. Alavia neli, n. gen. and n. sp.-The first Limoniidae (Diptera) from the Lower Cretaceous amber of Álava (Spain). Alavesia 2007, 1, 11-13.

28. Kania, I.; Krzemiński, W.; Arillo, A. First representative of the genus Helius Lepeletier and Serville, 1828 (Diptera, Limoniidae) from the Lower Cretaceous Álava amber (Spain). Cretac. Res. 2016, 63, 33-38. [CrossRef]

29. Kania, I.; Krzemiński, W.; Arillo, A. A new peculiar species of the genus Helius Lepeletier \& Serville, 1828 (Diptera, Limoniidae) from Cretaceous Álava amber (Spain). Earth Environ. Sci. Trans. R. Soc. Edinb. 2017, 107, 1-7.

30. Latreille, P.A. Histoire Naturelle, Generale et Particuliere, des Crustaces et des Insectes. Ouvrage Faisant Suite a l Histoire Naturelle Generale et Particuliere, Composee par Leclerc de Buffon, et Redigee par C.S. Sonnini, Membre de Plusieurs Societes Savantes. Tome troisieme. Familles Naturelles des Genres; Dufart: Paris, France, 1802; Volume i-xii, pp. 13-467.

31. Azar, D.; Gèze, R.; Acra, F. Lebanese Amber. In Biodiversity of Fossils in Amber from the Major World Deposits; Penney, D., Ed.; Siri Scientific Press: Manchester, UK, 2010; pp. 271-293.

32. Doria, G.; Royer, D.L.; Wolfe, A.P.; Fox, A.; Westgate, J.W.; Bereling, D.J. Declinic atmospheric $\mathrm{CO}_{2}$ durring the Late Middle Eocene climate transitin. Am. J. Sci. 2011, 311, 63-75. [CrossRef] 